運動生理 8(1):35-38,1993.

研究論支

\title{
立位および坐位の姿勢保持能力と下肢の ラテラリゼーションについて
}

木村 かおり ${ }^{1)}$ 宮下 国子

Effect of lateralization of Lower Limbs on the Ability to Maintain Standing and Sitting Postures.

Kaori KIMURA, RPT ${ }^{1}$ ), Kuniko MIYASHITA, OTR.

1) Department of Rehabilitation, Sousen Hospital: 2592 Sarashina-cho Wakaba-ku Chibacity 256 Japan. TEL +81 043-237-5001.

J. Exerc. Physiol. 8(1):35-38,1993. Submitted 0ct.2,1992. Accepted Dec. 20,1992. ABSTRACT

In order to examine how the lateralization of lower limbs affects the standing or sitting posture, we prescribed the exercise with the single limb stabilized for 20 healthy subjects, and their static standing balance and sitting balance were evaluated by the measurement of body sway. After the exercise, stableness of a supporting limb was found to become prominent. Body sway in a standing posture became smaller after the exercise with the left leg stabilized than after that with the right leg stabilized. Even in a sitting posture, body sway tended to become smaller after the exercise with the left leg stabilized. These imply the importance of left leg as a supporting limb. In addition, the exercise with the left leg stabilized caused the other side of body to become more stable. There was no correlation in regard to the change rate of body sway between in standing and sitting postures.

Key words: lateralization, stableness, exercise with the single leg stabilized 要旨

健常成人 20 名に対し、片脚支持訓練を施行したところ、支持脚の安定性が向上した。また、 左脚支持訓練によって、右脚支持訓練に比べ立位の重心動摇が減少し、坐位でも動摇が減少す る傾向がみられ、支持脚としての左脚の重要性が窥えた。左脚支持訓練によって反対側にも安 定が得られる傾向がみられた。立位と坐位の動摇の変化率については相関は得られなかった。 Key words：ラテラリゼーション、安定性、片脚支持訓練

1)誠馨会総泉病院リヘビリラーション科: 千葉市若葉区更科町2592（テ265） TEL 043-237-5001.

受付日1992年10月2日 受理日1992年12月20日 


\section{I 緒言}

中枢神経系疾患の患者を治療するにあたり、 私たち治療者が考慮すべきことは、まずその 法則性を理解することである。そして個々の 患者の解決されるべき問題点と照らし合わせ て患者の潜在性を引き出せる治療法を選択す ることである。これまで経験的であるとして 批判的であった治療法も中枢神経系の法則に したがって理論構築され、体系化されること によってそのような批判は過去のものとなり、 科学的な治療として広く理解が得られること が期待できる。

これまで中枢神経系の特徴として最も注意 を払われてきたのはHierarchyであり、Jacson の法則 ${ }^{1}$ である。前世紀に打ち立てられた神 経系の各レベルにおける機能の分化と統合に ついての理論は今だ色あせることなく我々に 多くの示唆を与えてくれる。しかし、神経系 の垂直方向への解明が進む一方で、水平方向、 すなわちLateralizationへの理解も重要であ ることが判ってきた ${ }^{2)}$ 。左右の分化と統合へ の理解は片麻疸患者における左右分断の問題 を解明する手掛かりとなることは間違いない。

片脚支持訓練が立位バランスの向上につな がるとしたTropp ${ }^{3)} や G a u f f i n n^{4)}$ の報告は、一 側の優位性がバランスに与える影響を考える 上で大変興味深い。そこで、われわれは下肢 のLateralizationが立位と坐位にどのように 影響するかについて検討するために、左右一 方の下肢を支持脚として訓練を施行した。そ して、静的バランスと坐位バランスを重心動 摇測定によって評価し、その影響について若 干の知見を得たので報告する。

\section{II対象および方法}

女6名)に分け、さらに訓練群は右脚支持群 (以 下Rt-Ex群) 5 名、左脚支持矺練群 (以下Lt-Ex群) 5 名に分け、訓練を施行した。

方法：

(1) 重心動摇計測

訓練前に被験者 20 名の立位、坐位、左右の 片脚立位の重心動摇を各3回計測した。1週間 の訓練後、同様の計測を行い、その平均値を 比較した。訓練群は以下に述べる訓練直前/ 直後に立位、坐位の重心動摇を毎回計測した。 計測肢位は立位では開眼、閉脚位で重心動摇 計（アニマ社製Gravicorder SG-1)に立ち、20 秒間、坐位では足部が床面に接地しない座面 をつくり、20秒間計測した(図1、2)。

(2) 訓練群は、以下の訓練を1日1回6日間行っ た。床面に十字形をマークし、被験者はその 中央に、左右いずれかの脚を支持脚にして片
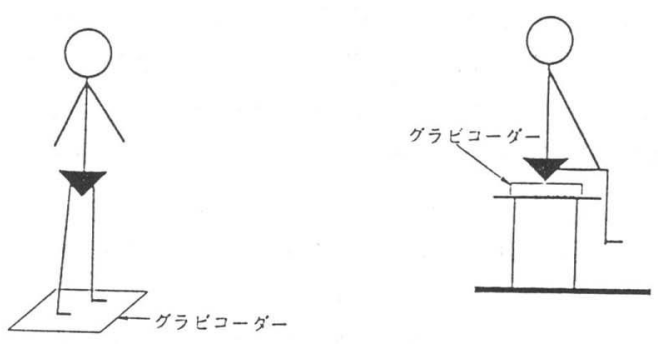

図 1

図2
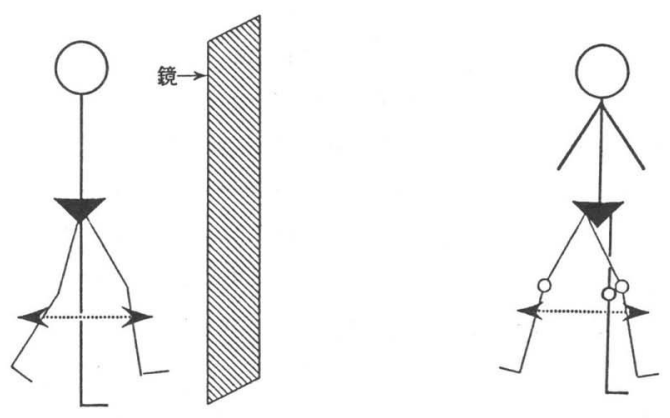

対象：健常人 20 名、平均年齢 $25.8 \pm 4.6$ 歳を 
表1 両足立位の重心動摇変化

\begin{tabular}{|c|c|c|}
\hline & ※ 変化率 $(\%)$ & 有意差 \\
\hline 訓 練 群 & $-14.4 \pm 31.1$ & なし \\
\hline 非訓練群 & $+19.6 \pm 58.3$ & なし \\
\hline$n=5$ & ※ 変化率（\%) & 有意差 \\
\hline 右訓練群 & $+14.0 \pm 42.0$ & なし \\
\hline 左訓練群 & $-8.7 \pm 58.3$ & なし \\
\hline
\end{tabular}

* $(E \times$ 後 $-E \times$ 前 $) \div E \times$ 前

表 3 訓練直後の立位・坐位での

\begin{tabular}{|c|c|c|}
\hline \multicolumn{3}{|c|}{$\langle$ 立立 $>n=30$} \\
\hline 訓 練 & 重心動摇変化 $\left(\mathrm{mm}^{2}\right)$ & 有意差 \\
\hline 右脚訓練 & $+4.1 \pm 5.0$ & $p<0.1$ あり \\
\hline $\begin{array}{l}\text { 左脚訓練 } \\
\text { 〈坐位 }\rangle=3=3\end{array}$ & $\frac{1+0.7 \pm 13.6}{0}$ & なし \\
\hline 訓 練 & 重心動摇変化 $\left(\mathrm{mm}^{2}\right)$ & 有意差 \\
\hline 右脚訓練 & $+0.03 \pm 0.3$ & なし \\
\hline 左脚訓練 & $-0.4 \pm 1.2$ & あり \\
\hline
\end{tabular}

表 5

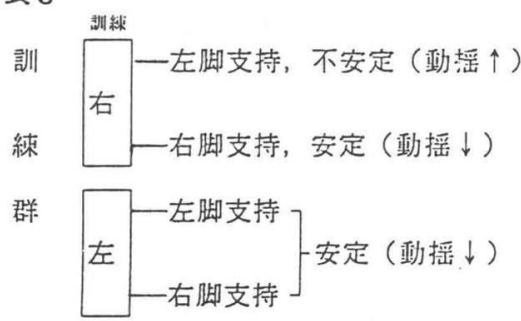

脚で立つ。もう一方の脚を遊脚としてマーク に沿って前後、左右に 15 秒ずっ 1 分間 64 回の速 さでメトロノームに合わせて動かす。前方に 鏡を設置し、視覚的なフィードバックを促す (図3)。

\section{III 結 果}

(1) 雨脚立位の重心動摇面積 (以下 SD-A)

（表1）訓練群、非訓練群とも有意差はなかっ たが、訓練群では訓練前に比べ、平均 $14.4 \%$ 動摇が減少している。訓練群のなかでも LtEx群に比べ動摇が減少する傾向がみられる。

(2) 片脚立位の重心動摇の変化 (表2)

訓練後の片脚立位のSD-A は、 Lt-Ex群では左 脚立位が $21.5 \%(p<0.05)$ で有意に減少し、右
表 2 片脚立位の重心動捊変化

\begin{tabular}{|c|c|c|c|}
\hline 赥 練 & 部 谓 & 助据の倠化 $(\mathbf{x})$ & 有剪煎 \\
\hline \multirow[b]{2}{*}{ 右啡测緗 } & 右片此立位 & $-17.8 \pm 42.1$ & $x$ \\
\hline & 左片趾立位 & $+11.2 \pm 111.9$ & $x$ \\
\hline \multirow[b]{2}{*}{ 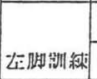 } & 右片趾立位 & $-35.9 \pm 31.8$ & $x$ \\
\hline & 左片跑立位 & $-21.5 \pm 15.0$ & (a) \\
\hline
\end{tabular}

\section{表4 左右の変化率の比較}

$$
n=5
$$

\begin{tabular}{|l|l|l|}
\hline & 右片脚立位 & 左片脚立位 \\
\hline 右脚訓練 & $-149.5 \pm 166.2$ & $-4.8 \pm 136.3$ \\
\hline 左脚訓練 & $-106.8 \pm 285.8$ & $-33.3 \pm 45.7$ \\
\hline
\end{tabular}

(\%)

は $35.9 \%$ 減少している。

Rt-Ex群では左右とも有意差はないが、左脚 立位が $41 \%$ 増加し、反対に右片脚立位は 17.8 \%減少している。

(3)立位と坐位での重心動摇の変化(表3)

訓練直後の計測で Rt-Ex群は立位のSD-Aが 有意に増加し $(p<0.01) 、 L t-E x$ 群は直後の坐 位が有意に減少している $(p<0.001)$ 。

(4) 左右の変化率の比較 (表 4)

訓練群における立位と坐位のSD-Aの相関は、 左右とも認められなかった。

\section{IV 考 察}

今回、われわれは、バランス維持に必要な 上位中枢の姿勢制御機構による運動の学習効 果について考慮し、被験者に片脚で支持した 感覚を覚えさせ、フィードバックさせること を目的に訓練を施行した。つまり、片脚での 支持は、筋力強化や末梢からの固有受容器機 能の改善といった効果を意図したものでなく、 sensori-motor unitへの運動制御の学習とし ての効果を考えている。その結果として、片 脚立位では、Rt-Ex群の右片脚立位の動摇は減 
少する傾向がみられたが、左脚支持が不安定 になることがわかった。一方、Lt-Ex群では左 脚立位の支持性が有意に高くなっており、右 も動摇が減少する傾向がみられた。(表5)これ

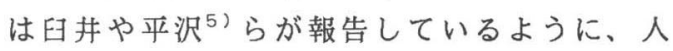
間の本来の支持脚は左であるという説に合致 するところがある。つまり、本来の支持脚が 左であれば、生来獲得されてきた左脚主軸の 立位バランスをより強化することによって安 定性が得易いことが考えられる。

左脚訓練の結果、反対側のバランスが向上 する点については運動プログラムの一般化 ${ }^{6)}$ という考え方もできるが、大脸半球の転移に よっても説明できるかもしれない。

半球間転移の問題については、梘覚組織に ついての分析が最も進んでいるが、身体感覚 の一部には反対側だけでなく、同側にも投射 する経路が存在すると言われている7)。つま り、左脚支持訓練によって本来のバランス維 持能力が強化され、感覚フィードバックの効 果が右に転移されたのではないかと考える。 一方、坐位でも変化率を求め、立位と比較し たが、SD-Aの相関は認められなかった。Carr とShepherdは “成人のバランス活動の『sequence』については証明されていない”こと をふまえて“坐位バランス訓練がそのままバ ランスの獲得につながることは期待すべきで ない”としている8)。しかし、坐位でもLt-Ex 群の訓練直後のSD-Aが有意に減少し、Rt-Ex群 は変化がなかった。つまり、坐位においても 立位と同樣に右よりも左への支持訓練が効果 的と考えられる。このように、両者のバラン ス活動が同じような傾向を示すこと、関連性 があることが伺える。

$$
\text { V まとめ }
$$

(1) 健常人 20 名を実験群 10 名、非実験群 10 名に 分け、さらに実験群を5名ずつ左脚支持訓
練群、右脚支持訓練群とし、それぞれに訓 練を施行し、重心動摇の变化を計測した。

(2)片脚支持訓練によって支持脚の安定性が向 上した。

(3)右脚支持訓練に比べ、左脚支持訓練の立位 における重心動摇が減少することがわかっ た。

(4)左脚支持訓練によって、坐位の重心動摇が 減少する傾向にあることがあることがわか った。

(5)訓練による重心動摇変化率は、坐位と立位 で有意な相関はなかった。

本論の要旨は第27回日本理学療法士学会に て発表した。

\section{引用 文 献}

1) 中村隆一: 運動障害と大脳半球の機能分化. 東北医誌, 92:63-66, 1979 .

2)豊倉康雄: 神経系におけるHierarchyと Lateralizationさらに左右への統合へ. 神経進歩, $24(3): 461-463,1980$.

3) Tropp H, et al: Factors affecting stabilometry recording of single limb stance. Am J Sports Med.,12:185-188, 1984.

4)Gauffinn: Effect of ankle disk training on postural control in patients with functional instability of the ankle joint. Int $\mathrm{J}$ Sports Med., 9: 141-144, 1988 .

5) 平沢一郎: 直立歩行を支える左足. アメリリかンサ仜 ンス.

6) 中村隆一・他: 運動学習・1, 運動学習の基礎. 理・作・療法 , 22(1), 1988 .

7)M.S.がザニカ,J.E.レドウー:ニつの脳と一つの心. ミ枕ヴァ書房。 